\title{
Punctate palmoplantar keratoderma type 2
}

INSERM

\section{Source}

INSERM. (1999). Orphanet: an online rare disease and orphan drug data base. Punctate palmoplantar keratoderma type 2. ORPHA:79502

Punctate palmoplantar keratoderma type 2 is a type of isolated, punctate, hereditary palmoplantar keratoderma characterized by multiple, asymptomatic, 1 to $2 \mathrm{~mm}$-long, firm, hyperkeratotic projections ("spiny keratosis") on the palms, soles and digits (typically confined to their volar and/or lateral aspects). Histopathologically, compact columnar parakeratosis over hypo- or agranular epidermis is observed. 